\title{
Learning Management in Suburban Schools During the Midst of COVID-19
}

\author{
Bernadetha Nadeak $^{1}$, Lamhot Naibaho ${ }^{2}$, Sunarto $^{3}$, E. Handayani Tyas ${ }^{4}$, Elferida Sormin ${ }^{5}$ \\ ${ }^{1,4}$ Postgraduate Program, Magister of Education Management, Universitas Kristen Indonesia \\ ${ }^{2}$ Faculty of Education and Teacher Training, English Education Department, Universitas Kristen Indonesia \\ ${ }^{3}$ Faculty of Education and Teacher Training, Biology Education Department, Universitas Kristen Indonesia \\ ${ }^{5}$ Faculty of Education and Teacher Training, Chemistry Education Department, Universitas Kristen Indonesia \\ Email : ${ }^{1}$ bernadetha.nadeak@uki.ac.id
}

\begin{abstract}
This study was conducted to determine how the teachers manage to learn in suburban schools during COVID-19. This thesis was conducted at Kristen Indonesia University. The method of this study was quantitative research with a survey design. The instrument used was a set of questionnaire which consisted of 24 statements. Two hundred thirty-five teachers involved in this research. The findings of the analysis showed that $85 \%$ of the teachers find it difficult in managing the learning at schools because most of the students do not have laptops, $87 \%$ of the teachers said that it is difficult to get in touch with the students for having low signal and wasteful of using data packages because many students lived far from urban areas. Teachers are deemed ineffective because as many as $83.5 \%$ of teachers stated that their students are not familiar with online before the COVID-19 Pandemic. The conclusion is that it is clear from various points of view that COVID-19 is a disaster that affects almost all sectors of human life, including teaching. However, it cannot be denied that the Pandemic of COVID-19 also provides educational institutions with the opportunity to become technology literate. The implementation of online teaching has become a catalyst for advancing the process of digital transformation of Indonesian learning.
\end{abstract}

Keywords

Teacher; learning management; suburban; covid-19

Article Received: 16th October, 2020; Article Revised: 30th December, 2020; Article Accepted: 08th January, 2021

\section{Introduction}

The whole world is now busy with various COVID-19 prevention efforts to contain the spike in positive patients because until now, there is no cure or vaccine yet. The government has made several policies to stop the spread of COVID-19, For eg, the closing of areas that are now included in the red zone for the transmission of the virus or actual quarantine to deter the virus from arising through physical interaction. The President of Indonesia has also published various health protocols. Implementing the physical distancing policy,which then becomes the basis for implementing learning at home, by utilizing information technology that applies suddenly, Implement a physical distance policy, which then becomes the cornerstone for home education, by using information technology that is unexpectedly introduced, also surprises instructors, teachers, and parents when they are not ready."Educators are shocked because they have to change the Studying proccess, and was originally face-to-face learning; now, all studying is done online" $[1 ; 2]$. The policies for implementing "online education carried out by schools and universities in response to the COVID-19 pandemic have hit almost the entire world" [3]. The "Indonesian Ministry of
Education and Culture encourages implementing the learning process to be carried out online. It is following the Circular of the Minister of Education and Culture of the Republic of Indonesia number 3 of 2020 concerning the Prevention of Corona Virus Disease (COVID-19) in the Education Unit as well as following the circular and appeals from the respective Regional Governments that domicile Higher Education" [4]. Information technology is "a solution for implementing online teaching and the educators can use it to carry out learning online" $[5 ; 6 ; 7]$. Information technology to support online learning implementation during this Pandemic includes Microsoft Teams, Zoom, and other online LMS. After three months of implementing online learning, many complaints were experienced by students because of the unpreparedness of the facilities owned by students. Online teaching is also implemented at Suburban Schools, which requires all teachers and students to be technologically literate [8;9]. Teachers must prepare material in teaching materials and video tutorials before conducting online teaching [10]. Likewise, students must study harder to be able to understand the material provided by the teacher online. The online learning process has not been carried out optimally because of teachers' and 
students' unpreparedness, so that it needs adjustments first $[11 ; 12]$. Many students have limited facilities to support online teaching. Starting from the limited signal, Inadequate use of packets of data, several students that do not have computers, many students do not live in cities, but live in remote/mountain areas away from internet access. This situation can cause the learning gap to get stronger. It indicates that there are many challenges faced in online learning using information technology $[13 ; 14]$. However, in addition to these obstacles, there are ways to use information technologies that teachers continue to learn in a creative manner. Of course, it will be instrumental in the world of learning and the digital era. Studying and teaching during the COVID-19, there are several opportunities and challenges faced in using information technology to support educational activities $[15 ; 16]$.

The use of information technology in evaluation activities through online learning systems shows the effectiveness of this information technology in supporting learning and evaluation as long as it is used appropriately and with adequate carrying capacity $[17 ; 18]$. Although the thesis looks close to this analysis, the condition of COVID-19, which has an effect on learning psychology, makes it distinct. In addition, the topics addressed by this information technology are distinct, meaning that there are new items that can definitely be confirmed by the two previous research. Based on the explanation of the background of the problem above, there was an interest in researching the opportunities and barriers for the use of artificial intelligence in digital training at the Suburban Schools during the COVID-19 Pandemic.

\section{Theoretical Review}

Management of learning can be described as "the process of managing which includes planning, organizing, controlling (directing) and evaluating activities related to the learning process of the learner by including various factors in it to achieve goals" [19]. In managing learning, "the teacher carry out various steps of activities ranging from planning learning, organizing learning, directing and evaluating the learning carried out" [20]. The "notion of learning management can be interpreted broadly in the sense that it includes all activities on how to teach students from learning planning to learn assessment" [21]. The other view notes that "learning management is part of a learning strategy, namely a learning management strategy" [22].

Learning management is "one of the management of competency-based curriculum implementation" [23]. Other "management includes human resource management, facilities management, and appraisal management" [24]. The "things that need to be considered in terms of learning management are as follows; teacher-student activity schedule; learning strategies; practice material management; management tools; team learning; remedial and enrichment programs; and improving the quality of learning" [25]. "The definition only relates to activities that occur during classroom interaction, both outside and inside the classroom" [26]. This understanding can be said to be the concept of Regulation of learning in a narrow context. Before concluding some of the descriptions of experts about learning power, it is better to read a brief description of the understanding of learning management. Learning management is all efforts to regulate the teaching and the method of students to achieve an effective and productive teaching and learning process. Learning program management is often referred to as curriculum and learning management.

Learning management is the "arrangement of all learning activities, whether categorized based on the core or supporting curriculum based on the pre-determined curriculum, by the Ministry of National Education" [27]. Based on the several statements above, it can distinguish the "concept of learning management in a broad sense and a narrow sense" [28]. Learning management in the "broadest sense contains the process of managing how to teach the learner with activities starting from planning, organizing, directing or controlling and assessing" [29]. Meanwhile, learning management, "in a narrow sense is defined as activities managed by the teacher during the interaction process with students in the implementation of learning" [30]. Management is defined as the teacher's effort or action as the leader of learning in the classroom. It is done to obtain results and to achieve school learning programs' goals. 
During the Pandemic, the government implemented work from home or working at home, and the community was required to carry out social distancing. It aims to avoid the spread and transmission of the coronavirus by carrying out activities at home. In this case, in the education sector, learning is carried out online. Universities are required to be able to organize online or online learning. It is following the Minister of Education and Culture of the Republic of Indonesia's decision regarding Circular Number 4 of 2020 concerning the "implementation of Education Policies in an Emergency for the Spread of Corona Virus Disease" [31; 32]. Online Studying is "an option to replace the face-to-face teaching system directly during the COVID-19 pandemic, and this choice also coincides with the use of social media to support learning achievement" [33]. The situation impact the "critical thinking skills of students who are required to survive, adapt to attend teaching with the new system, students are required to be skilled in using social media, familiar with the online system so that they can keep up with all learning" [34]. Education is "currently required to answer the challenges of the 21 st century, which can produce graduates who have the ability of $6 \mathrm{C}$ for HOST" [35]. One of which is critical thinking, which is expected to be achieved by graduates where the crucial goal in critical thinking is that students can think deeply, logically, collect, and evaluate evidence with specific disciplines as a result of studying the core subject disciplines [36].

In this case, students must be able to think objectively of the diverse knowledge they obtain through the use of social media. The ability to think critically makes a person able to critically analyze and evaluate by using multiple mental processes such as focusing, categorizing, selecting, and assessing [37]. Critical thinking skills are needed in Education because through necessary thinking skills, andstudents can prepare themselves for situations and conditions. Through the ability to think critically, students will come to understand themselves and be able to understand the world and their environment [38]. When it is related to information processing in learning, students are directed to think critically at the learning process that processes information. Compared to just being a passive recipient of information, promoting critical thinking supported by the right learning model will further improve student understanding [39]. In the process of critical thinking, students are directed to be able to focus their minds on processing and understanding any information. After going through this necessary thinking process, it is hoped that students will have the ability to analyze and respond to information appropriately. Students' use of digital media can influence students' learning outcomes themselves [40]. The use of social media as the correct learning media can improve student learning achievement, which impacts learning outcomes. If student learning achievement is high, the learning that has been carried out has been successful and the learning outcomes arranged have been fulfilled. The correct use of social media will benefit knowledge and improve learning outcomes [41]. Besides, social media can positively influence users because social media provides the freedom to seek information without any time and space limitations. When a pandemic occurs, the face-toface learning period must be stopped, and social media becomes the main facility in increasing social interaction between students and teachers so that they can communicate easily and quickly [42].

It is anticipated that the use of social media can support the learning process and promote contact between teachers and students during the Covid 19 pandemic. Effective and fast communication will facilitate the learning delivery process [43]. A fair learning process is "expected to create and improve learning achievement or learning outcomes of students who are good too. Based on the results of research on students, it shows that the use of social media correctly effectively improves learning outcomes" [44]. Furthermore, the use of digital networking by scholar can affect student achievement. The use by students of social networking media as learning media, the higher their learning achievement. Likewise, the decreasing use of digital media as a learning medium will lower learning achievement. In the digital era that has used technology as one of the main tools in obtaining information, social media has become an option in the online learning process, especially during the COVID-19 Pandemic. Although it cannot be denied that the learning process during the COVID-19 period 
depended on the use of learning media and

\section{Methods}

This research uses research and interview techniques in the library. Library review is a study used to gather information and data from a range of library resources, such as records, books, journals, historical stories, news, etc. Meanwhile, according to library research experts, It is a theoretical research, sources, and other scientific literature related to society, beliefs, and norms established in the social situation under study. Data collection was collected from news and papers in online publications in this review. The researcher searched for objects using the

\section{Results}

The adoption of a regulation on physical distance, which later formed the basis for the incorporation of online teaching, through the application of information technology, which has unexpectedly taken place, shocked teachers and students because they were not ready. Some teachers were shocked because they had to change the learning system, which initially studied face-to-face. Now all learning is done online. In detail, the findings obtained in this study are described as follows.Based on the questionnaire data, information was obtained about online teaching during the COVID-19Pandemic. There were still many students of the Suburban Schools who were not ready for online Education. The description of the data taken through a questionnaire is $85 \%$ of students stated that they do not have laptop facilities and $61 \%$ of students in online teaching use cellphones as a medium for online teaching. These statistics indicate that there are already a number of students who have not completely embraced online schooling.

Changing the conventional learning paradigm to online, although not difficult, will take a long time. Because it is closely related to the paradigm shift in academic culture, as with the results of a survey of students, it was found that $83.5 \%$ of students before Covid 19 had never carried out online learning. Based on the survey data above, students are not ready to carry out this online learning because it involves academic culture, which includes values, attitudes, knowledge and students' critical thinking skills.

keywords "Impact of COVID-19" and "Online Learning." Survey study was undertaken by circulating questionnaires using the google method. The primary data of this study is by the dissemination of survey questions to participants. Respondents of this study were students of the Suburban Schools from totaling 235 teachers. The data collected from various data collection methods are then Processed and merged to gain explanations of the problems and opportunities for the application of information technologies in online learning services after the COVID-19 Pandemic.

skills, and the readiness of facilities and infrastructure related to information literacy among students. Ideally, this policy change concerning the learning paradigm is used as a momentum for students to freely and critically seek knowledge digitally. Likewise, learning opportunities can be free because they are not bound by a face-to-face presence [45]. Students can manage their time freely to meet the demands of their study assignments.

Thus, students will become literate with information related to their academic needs and continue to grow [46]. However, the reality is quite the opposite. There is a change in the learning paradigm. Students complain a lot, as evidence of internal student unpreparedness related to values, attitudes, knowledge, and skills to acquire, evaluate, and organize information. The students' unpreparedness was also caused by the geographic location of the Suburban Schools students, most of whom were far from cities, so that many students had difficulty getting an internet connection. Based on the survey results, it was found that as many as $87 \%$ of students experienced problems with signal problems and wasteful use of data packages when carrying out online teaching. It is an essential concern for the Suburban Schools institution because many students expect to get subsidized administrative costs. Given that it is uncertain when Education will normally run again.

As regards the prevention of COVID-19 in tertiary schools, the Ministry of Education and Culture, 
the 5th point which states "Organizing distance learning is following the conditions of each school and advises students to conduct learning from home with online learning both synchronous and asynchronously, through the following platforms: Google Classroom/Edmodo/Schoology/Classdojo (for kids), to record video material via Camtasia/Screencast-O-Matic/Seesaw/Xrecorder, and for training can be through Quizlet (flashcards and diagrams), Quizizz (homework) or Kahoot."Based on this circular, the Teaching System at Suburban Schools has been carried out with remote teaching using the Google Classroom, Edmodo, EdLink, Schoology, Zoom, and

\section{Discussions}

For teaching to be more interesting and students can understand the material presented, it requires teaching creativity from each teacher, such as providing material explanations using video, teaching combined with Zoom video conferencing, or other applications to explain the material to be given to students.Indonesia's education sector's digital transformation is not a new discourse, various conversations, supporting regulations, and substantial efforts to implement digital change in universities and all school levels in Indonesia. Previously, multiplelessons, supporting policies, and socialization about the industrial era 4.0 had not succeeded in making the education industry for universities, institutes, high schools, polytechnics, academies, and secondary schools) achieve significant progress in the digital transformation of Indonesian Education, COVID19 , or the Corona Virus has an extraordinary impact on this aspect [47]. In terms of various elements, it is clear that COVID-19 is a disaster that harms almost all human life sectors.

Especially efforts to prevent the spread of COVID-19 through Large-Scale Social Restrictions on different appeals at home, work from home, Study From Home, Sit Home, among others. However, it cannot be argued that the catastrophe caused by the COVID-19Pandemic has had various beneficial consequences, such as better natural conditions. In the field of Education, it has become a trigger for accelerating the digital transformation of Indonesian Education.All colleges and schools in Indonesia stopped face-toface teaching and learning activities. However, of
Whatshap Group platforms. Based on the survey results from the use of online teaching applications, it is stated that the application most used by teachers and students of the Suburban Schools is Google Classroom with $40 \%$, the second Whatshap group is $39 \%$, the third Schoology is $15 \%$, then Edmudo 3\%, Edlink $2 \%$, and Zoom 1\%. The use of the Google classroom and Whatsapp Group media has become very attractive to teachers and students of the Suburban Schools because it is straightforward to understand and can be reached by students' signals and data packages.

course, the teaching and learning process must not stop; now, everyone must carry out online learning. Like it or not, you can or cannot, feel clueless or not. The result is that the dominant teachers, teachers, students, and students are currently getting proficient in using various tools and media to support online learning. However, it may face multiple obstacles and limitations.

However, this is progress that should be grateful and used to utilize technology in the learning process. Webinars are short for web seminars, which are seminars conducted through internetbased applications such as zoom, google meet, jitsi,etc. With webinars, it is possible to process knowledge transfer without limitation of distance and space. Since the restriction of social activities for preventingCOVID-19 in Indonesia, many teachers and educators have conducted webinars. There have been many webinar activities that have been carried out, including several teachers at the Suburban Schools. Some webinars are paid for, and also many offer quality webinars for free. It is undoubtedly an indication of positive development for the digital transformation of Education in Indonesia.Education 4.0 can be seen as a creative response where humans take advantage of digital technology, open sources contents, and global classrooms in the application of lifelong learning, flexible education systems, and personalized learning how to play a better part in society.

On the other hand, new regular e-learning learning is not an answer to a question but an adaptation of a condition that everyone is "forced" to do. After the COVID-19 epidemic, the new regular 
education should be continued and refined to meet blended learning. This educational concept combines face-to-face teaching methods in classrooms with e-learning. In turn, the world of education will genuinely is in the era of education 4.0. Regarding e-learning in higher education, if the measure is "doable," it cannot be denied that all campuses can do it.

Teachers and students are expected to at least understand the application of new media. On the other hand, students are often required to explore information technology and channel their imagination into developments in assigned assignments. Various information technology tools have the potential that will be used to facilitate online course programs and, at the same time, often have the opportunity to compel teachers to become literate in information technology. Any of them are as follows: elearning, Edmodo, EdLink, Moodle, Google Classroom, Online Schoology Class. Of the several digital mode platforms mentioned above, Whatsapp is the most familiar among students and teachers of the Suburban Schools because, before the COVID-19Pandemic, students and teachers had also been intensively communicating and interacting learning through WhatsApp groupscommunicating and interacting learning through WhatsApp groups.

However, during this Pandemic, teachers should use online learning to develop digital competences so that each teacher's digital mode can be more varied. It aims to avoid student boredom in Education and absorb information related to teaching materials and avoid monotonous patterns carried out by most of the teachers. Conventional

\section{Conclusion}

The media most widely used in online learning at Suburban Schools is the Google Classroom and Whatshap group because it is straightforward to use. There are, however, some challenges faced, For example, insufficient facilities. Based on the findings of the survey stated that $85 \%$ of students do not have laptops, $87 \%$ said this became difficult to get a signal and wasted the use of data packets. This was because a lot of students were living far away from urban centres. Most believe that online instruction is unsuccessful because it is systems that have occurred so far should be integrated with multimedia communication media, especially since the discovery of this multimedia communication media. Owing to the existence of the internet and can be contacted at any moment, students can take advantage of the instructional services available on the internet at any time, based on their free time. Space and time limitations that they face in seeking learning opportunities can be solved. With the rapid development in telecommunication, multimedia, and information technology, listening to teaching, taking notes on paper is undoubtedly out of date. Various new terms emerged in learning using the internet for eg, online learning, distance learning, web-based learning, e-learning [48].

The exponential advancement of technology is currently the gateway to the advent of Industrial Revolution 4.0 or Manufacturing 4.0. Industry 4.0 is a cyber-physical framework, which ensures the technology is no longer a 'tool' but is rooted in people's lives. [49]. Artificial Intelligence, nanotechnology, biotechnology, autonomous vehicles, and 3D printing are examples of today's widespread development of technology. Speed, reach/coverage, and impact are three reasons which explain that the current technological transformation is not an extension of the third industrial revolution but the arrival of the industrial revolution 4.0. Some of these applications can be the first step for higher Education when compiling e-learning in implementing Blended Learning to realize Education 4.0, which will become a New Normal in the era of Industrial Revolution 4.0 after the COVID-19Pandemic.

not used to online education, so they need adjustments first. It is also because, before the COVID-19Pandemic, $83.5 \%$ of students stated that they had never used online teaching mediaIn relation to various facets, it is obvious that COVID-19 is a catastrophe which affects almost every field of human life, including education.

However, it could be forgotten that the virus outbreak already presents educational institutions capable of being technologically literate. Implementation of online teaching has been a catalyst for accelerating the process of digital 
transformation of Indonesian education. Previously, multiple discourses, policy funding, and socialization on the modern age 4.0 have struggled to make the education sector of universities, institutes, high schools, polytechnics,

\section{References}

[1] Nakhostin-Ansari, A., Sherafati, A., Aghajani, F., Khonji, M. S., Aghajani, R., \&Shahmansouri, N. (2020). Depression and anxiety among Iranian Medical $\begin{array}{lll}\text { Students during COVID-19 } & \end{array}$ Pandemic. Iranian Journal of Psychiatry, 15(3), 228.

[2] Nadeak, B., Naibaho, L., \&Silalahi, M. (2020). COVID-19 and Students' Anxiety Management. International Journal of Innovation, Creativity, and Change, 13(7), 1574-1587.

[3] Crawford, J., Butler-Henderson, K., Rudolph, J., Malkawi, B., Glowatz, M., Burton, R., ...\& Lam, S. (2020). COVID19: 20 countries' higher education intraperiod digital pedagogy responses. Journal of Applied Learning \& Teaching, 3(1), 120.

[4] Yuniartob, B. (2020). The Impact of Covid-19 on the Indonesian School Learning Process. PalArch's Journal of Archaeology of Egypt/Egyptology, 17(3).

[5] Baran, E., Correia, A. P., \& Thompson, A. (2011). Transforming online teaching practice: Critical analysis of the literature on the roles and competencies of online teachers. Distance Education, 32(3), 421439.

[6] Naibaho, L., \& Ambrosia, Y. (2019). Students' Perception on Guessing Game Use in Learning Vocabulary at SMPK Ignatius SlametRiyadi.

[7] Moreno-Ger, P., Burgos, D., MartínezOrtiz, I., Sierra, J. L., \&FernándezManjón, B. (2008). Educational game design for online education. Computers in Human Behavior, 24(6), 2530-2540.

[8] Guzey, S. S., \&Roehrig, G. H. (2009). Teaching science with technology: case studies of science teachers' technological pedagogical content knowledge (TPCK). Contemporary Issues in academies, and secondary schools a major step forward in the digital transition of Indonesian education, the Corona Virus; it has had a huge effect on the digital revolution into the 4.0 age of education.

Technology and Teacher Education, 9(1), 25-45.

[9] Varier, D., Dumke, E. K., Abrams, L. M., Conklin, S. B., Barnes, J. S., \& Hoover, N. R. (2017). Potential of one-to-one technologies in the classroom: teachers and students weigh in. Educational technology research and development, 65(4), 967-992.

[10] Digeyasa, I. W., \&Naibaho, L. (2020). The Use of Google on Completing English Assignment by the Students of English Education Department at UniversitasNegeri Medan. International Journal of Research, 8(6), 150-155.

[11] Wong, J., Baars, M., Davis, D., Van Der Zee, T., Houben, G. J., \&Paas, F. (2019). Supporting self-regulated learning in online learning environments and MOOCs: A systematic review. International Journal of HumanComputer Interaction, 35(4-5), 356-373.

[12] Schonert-Reichl, K. A., Hanson-Peterson, J. L., \&Hymel, S. (2015). SEL and preservice teacher education. Handbook of social and emotional learning: Research and practice, 406-421.

[13] Zaidieh, A. J. Y. (2012). The use of social networking in Education: Challenges and opportunities. World of Computer Science and Information Technology Journal (WCSIT), 2(1), 18-21.

[14] Liu, X., Liu, S., Lee, S., \&Magjuka, R. J. (2010). Cultural differences in online learning: International student perceptions. Educational Technology \& Society, 13(3), 177-188.

[15] Rapanta, C., Botturi, L., Goodyear, P., Guàrdia, L., \&Koole, M. (2020). Online university teaching during and after the Covid-19 crisis: Refocusing teacher presence and learning activity. Postdigital Science and Education, 2(3), 923-945.

[16] Reimers, F., Schleicher, A., Saavedra, J., \&Tuominen, S. (2020). Supporting the continuation of teaching and learning 
during the COVID-19

Pandemic. Oecd, 1(1), 1-38.

[17] Nadeak, B., \&Naibaho, L. (2020). VideoBased Learning on Improving Students' Learning Output. PalArch's Journal of Archaeology of Egypt/Egyptology, 17(2), 44-54.

[18] Romero, C., Ventura, S., \&García, E. (2008). Data mining in course management systems: Moodle case study and tutorial. Computers \& Education, 51(1), 368-384.

[19] Nadeak, B., \&Naibaho, L. (2020). The Effectiveness of Problem-Based Learning on Students' Critical Thinking. JurnalDinamikaPendidikan, 13( 1), 1-7.

[20] Pedaste, M., Mäeots, M., Siiman, L. A., De Jong, T., Van Riesen, S. A., Kamp, E. T., ...\&Tsourlidaki, E. (2015). Phases of inquiry-based learning: Definitions and the inquiry cycle. The educational research review, 14, 47-61.

[21] Macfadyen, L. P., \& Dawson, S. (2010). Mining LMS data to develop an "early warning system" for educators: A proof of concept. Computers \&Education, 54(2), 588-599.

[22] White, C. (2008). Language learning strategies in independent language learning: An overview. Language learning strategies in independent settings, 3-24.

[23] Naibaho, L. (2019). The Integration of Group Discussion Method Using AudioVisual Learning Media TowardStudents'learning Achievement On Listening. International Journal of Research-GRANTHAALAYAH, 7(8), 438445.

[24] Odediran, S. J., Gbadegesin, J. T., \&Babalola, M. O. (2015). Facilities management practices in the Nigerian public universities. Journal of Facilities Management.

[25] Robbins, P. (2015). Peer coaching to enrich professional practice, school culture, and student learning. ASCD.

[26] Dailey-O'Cain, J., \&Liebscher, G. (2009). Teacher and student use of the first language in foreign language classroom interaction:

Functions

and applications. First language use in second and foreign language learning, 131-144.

[27] TemliDurmus, Y. (2016). Effective Learning Environment Characteristics as a Requirement of Constructivist Curricula: Teachers' Needs and School Principals' Views. International Journal of Instruction, 9(2), 183-198.

[28] Carr, D. (2005). Making sense of Education: An introduction to the philosophy and theory of Education and teaching. Routledge.

[29] Naibaho, L. (2019). Teachers'roles on English Language Teaching: A Students Centered Learning

Approach. International Journal of Research-Granthaalayah, 7(4), 206-212.

[30] Goldie, J. G. S. (2016). Connectivism: A knowledge learning theory for the digital age?. Medical teacher, 38(10), 1064-1069.

[31] Wajdi, M. B. N., Kuswandi, I., Al Faruq, U., Zulhijra, Z., Khairudin, K., \&Khoiriyah, K. (2020). Education Policy Overcome Coronavirus, A Study of Indonesians. EDUTECH: Journal of Education And Technology, 3(2), 96-106.

[32] Hua, J., \& Shaw, R. (2020). Coronavirus (Covid-19) "infodemic" and emerging issues through a data lens: The case of China. International journal of environmental research and public health, 17(7), 2309.

[33] Di Pietro, G., Biagi, F., Costa, P., Karpinski, Z., \&Mazza, J. (2020). The likely impact of COVID-19 on Education: Reflections based on the existing literature and recent international datasets. Luxembourg: Publications Office of the European Union.

[34] Richmond, J. E. (2007). Bringing Critical Thinking to the Education of Developing Country Professionals. International education journal, 8(1), 1-29.

[35] Subotnik, R. F., Olszewski-Kubilius, P., \& Worrell, F. C. (2011). Rethinking giftedness and Gifted Education: A proposed direction forward based on psychological science. Psychological science in the public interest, 12(1), 3-54.

[36] Naibaho, L. (2019). The Effectiveness of Number Head Together Strategy on Improving Students' English Achievement 
at XYZ School. International Journal of Research-GRANTHAALAYAH, 7(10), 362370.

[37] Facione, P. A. (2011). Critical thinking: What it is and why it counts. Insight Assessment, 2007(1), 1-23.

[38] Choy, S. C., \&Cheah, P. K. (2009). Teacher perceptions of critical thinking among students and its influence on higher education. International Journal of teaching and learning in Higher Education, 20(2), 198-206.

[39] Çavdar, G., \& Doe, S. (2012). Learning through writing: Teaching critical thinking skills in writing assignments. PS: Political Science \& Politics, 45(2), 298-306.

[40] Khan, T., Kend, M., \& Robertson, S. (2016). Use of social media by university accounting students and its impact on learning outcomes. Accounting Education, 25(6), 534-567.

[41] Churcher, K. (2014). " Friending" Vygotsky: A Social Constructivist Pedagogy of Knowledge Building through Classroom Social Media Use. Journal of Effective Teaching, 14(1), 33-50.

[42] Bowen, J. A. (2012). Teaching naked: How moving technology out of your college classroom will improve student learning. John Wiley \& Sons.

[43] Nadeak, B., Juwita, C. P., Sormin, E., \&Naibaho, L. (2020). The relationship between students' critical thinking skills and social media use on learning outcomes during the Covid-19 Pandemic. JurnalKonselingdanPendidikan , 8(2), 98-104.

[44] Merchant, Z., Goetz, E. T., Cifuentes, L., Keeney-Kennicutt, W., \& Davis, T. J. (2014). Effectiveness of virtual realitybased instruction on students' learning outcomes in K-12 and higher education: A meta-analysis. Computers Education, 70, 29-40.

[45] Watson, J. (2008). Blended Learning: The Convergence of Online and Face-to-Face Education. Promising Practices in Online Learning. North American Council for Online Learning.

[46] Hobbs, R., \& Jensen, A. (2009). The past, present, and future of media literacy education. Journal of media literacy education, 1(1), 1.

[47] Ratten, V. (2020). Coronavirus (Covid-19) and the entrepreneurship education community. Journal of Enterprising Communities: People and Places in the Global Economy.

[48] Tsai, S., \& Machado, P. (2002). ELearning Basics: Essay: E-learning, online learning, web-based learning, or distance learning: unveiling the ambiguity in current terminology. eLearn, 2002(7), 3.

[49] Wang, L., \& Wang, G. (2016). Big data in cyber-physical systems, digital manufacturing, and industry 4.0. International Journal of Engineering and Manufacturing (IJEM), 6(4), 1-8. 